\title{
Analytical Method Development and Validation of Metformin Hydrochloride by using RP-HPLC with ICH Guidelines
}

\author{
Mr. Nilesh Nikam¹, Dr. Avish Maru², Dr. Anil Jadhav³, Dr. Prashant Malpure ${ }^{4}$ \\ 1,4 Assistant Professor, 2,3Principal \\ 1,3Sandip Foundation, Institute of Pharmacy, Mahiravani, Nashik, Maharashtra, India \\ 2,4Loknete J. D. Pawar, College of Pharmacy, Manur, Kalwan, Maharashtra, India
}

\begin{abstract}
How to cite this paper: Mr. Nilesh Nikam | Dr. Avish Maru | Dr. Anil Jadhav | Dr. Prashant Malpure "Analytical Method Development and Validation of Metformin Hydrochloride by using RPHPLC with ICH Guidelines" Published in International Journal of Trend in Scientific Research and Development (ijtsrd), ISSN: 24566470, Volume-3 | Issue-3, April 2019, pp.415-419, URL: http://www.ijtsrd.co $\mathrm{m} /$ papers/ijtsrd228 12.pdf

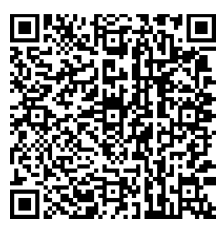
IITSRD22812

Copyright (c) 2019 by author(s) and International Journal of Trend in Scientific Research and Development Journal. This is an Open Access article distributed under the terms of the Creative Commons

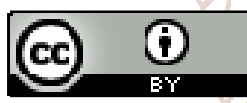
Attribution License (CC BY 4.0) (http://creativecommons.org/licenses/ by $/ 4.0$ )
\end{abstract}

\section{INTRODUCTION:}

Metformin is an agent having antihyperglycemic activity and belonging to the biguanide class of antidiabetic drugs. Metformin is analogous with a very low incidence of lactic acidosis. Metformin is the most commonly prescribed drug for the patients having type 2 diabetes mellitus. The literature survey says that, in addition to glucose lowering, several studies have presented evidence propose that some potential role for metformin, such as antitumor effect, cardiovascular protective effect, antiaging effect, neuroprotective effect or an optional treatment for polycystic ovary syndrome. The drug was approved in the United Kingdom in 1958 and in the United States in 1995 and since the doses were ranging from 500 to $2,500 \mathrm{mg} /$ day. According to study of Diabetic guidelines of American Diabetes Association/European Association it is the first-line therapy for patients with T2DM (type 2 Diabetes mellitus). The history of biguanides can be discover from the use of plant namely as Galega officinalis (commonly known as galega) for treating diabetes in medieval Europe. Guanidine, the active component of Galega officinal is, and it is the parent compound used to synthesize the biguanides. metformin has a superior safety profile and is well tolerated. The other two biguanides, phenformin and buformin, were withdrawn in the early 1970s due to the risk of lactic acidosis and increased cardiac mortality. The incidence of lactic acidosis with metformin at therapeutic doses is rare (less than three cases per 100,000 patient-years) and is not greater than with non- metformin therapies.<smiles>CN(C)C(=N)NC(=N)N</smiles>

Metformin Hydrochloride<smiles>CCCC[Mg]</smiles>

M.W. 165.63

Figure 1: Structure of Metformin Hydrochloride

The Guidelines for analysis method validation include ICH guidelines. By the literature survey a very few methods reported for determination of Metformin HCL in bulk drug as well as pharmaceutical preparation. This research is tries to develop a new sensitive and rapid HPLC method for the 
determination of Metformin HCL in Bulk preparation, and this method was also validated according to ICH Q2 (R) guidelines.

\section{MATERIALS AND METHOD: Instruments:}

The chromatographic separation was performed on Analytical Technologies HPLC-3000 series compact liquid chromatographic system integrated with a variable wavelength programmable UV detector and a Rheodyne injector equipped with $20 \mu \mathrm{l}$ fixed loop. A reverse phase C18 [Cosmosil C18 (250mm x 4.6ID, Particle size: 5 micron)] was used. Model - UV 2012 double beam UV visible spectrophotometer and Wenser High Precision Balance Model: PGB 100 electronic balance were used for Spectrophotometric determinations and weighing purposes respectively.

\section{Reagents and chemicals}

Pharmaceutical grade pure metformin hydrochloride sample was procured from Swapnaroop Agency. HPLC grade Methanol and HPLC grade Water were used of Merck specialities private limited, Mumbai.

\section{Chromatographic conditions}

C18 [Cosmosil C18 (250mm x 4.6ID, Particle size: 5 micron)] was used for the chromatographic separation at a detection wave length of $238 \mathrm{~nm}$. Methanol, Phosphate buffer $\mathrm{pH} 3$ in a ratio of 70:30 v/v was selected as mobile phase for elution and same mixture was used in the preparation of standard and sample solutions. The elution was monitored by injecting the $20 \mu \mathrm{l}$ and the flow rate was adjusted to 1 $\mathrm{ml} / \mathrm{min}$.

\section{Preparation of Mobile phase}

Preparation of Phosphate buffer $\mathrm{pH}$ 3: Dissolve $1.36 \mathrm{~g}$ of Potassium dihydrogen orthophosphate \& $2 \mathrm{ml}$ of triethylamine in $800 \mathrm{ml}$ of HPLC water, adjust the $\mathrm{pH}$ to 3 with orthophosphoric acid and add sufficient HPLC water to produce $1000 \mathrm{ml}$.The mobile phase was sonicated for $15 \mathrm{~min}$ and filtered through a $0.45 \mu \mathrm{m}$ membrane filter paper.

\section{Preparation of Standard solutions}

$10 \mathrm{mg}$ metformin was accurately weighed and transferred into $10 \mathrm{ml}$ volumetric flasks, dissolved using mobile phase and the volume was made up with the same solvent to obtain primary stock solution of concentration $1000 \mu \mathrm{g} / \mathrm{ml}$ of the drug. (Working stock solution).

\section{Preparation of Sample Solution}

20 tablets of metformin were initially weighed and powdered and an amount equivalent to $10 \mathrm{mg}$ was accurately weighed into a $10 \mathrm{ml}$ volumetric flask, mixed with $10 \mathrm{ml}$ of mobile phase. The solution was made up to the volume with mobile phase and sonicated for 5 minutes. The solution was then filtered through $0.45 \mu \mathrm{m}$ Millipore membrane filter. The solution contains $1000 \mu \mathrm{g} / \mathrm{ml}$ of metformin Hcl. From the above stock solution $0.1 \mathrm{ml}$ aliquot was transferred in to a 10 ml volumetric flask, volume was made up to the mark with mobile phase to obtain a final concentration of $10 \mu \mathrm{g} / \mathrm{ml}$ of metformin.

\section{Optimization of RP-HPLC method}

The HPLC method was optimized with an aim to develop a estimation of metformin Hcl. For the method optimization, different mobile phases were tried, but acceptable retention times, theoretical plates and good resolution were observed with Methanol, Phosphate buffer pH 3 (70:30 v/v) using C18 column [Cosmosil C18 (250mm x 4.6ID, Particle size: 5 micron)] Table: 1 .

\begin{tabular}{|c|c|}
\hline Parameter & Condition \\
\hline Column & $\begin{array}{c}\text { Cosmosil C18 (250mm x 4.6ID, } \\
\text { Particle size: 5 micron) }\end{array}$ \\
\hline Mobile Phase & $\begin{array}{c}70: 30 \text { (Methanol: Phosphate buffer } \\
\mathrm{pH}-3) .\end{array}$ \\
\hline Flow Rate & $1 \mathrm{ml} / \mathrm{min}$ \\
\hline Wavelength & $238 \mathrm{~nm}$ \\
\hline Injection Volume & $20 \mu \mathrm{l}$ \\
\hline Detector & UV-3000-M \\
\hline Run Time & $6.5 \mathrm{~min}$ \\
\hline Retention Time & Approx. $4.2 \mathrm{~min}$ \\
\hline
\end{tabular}

Table 1: Optimized parameter

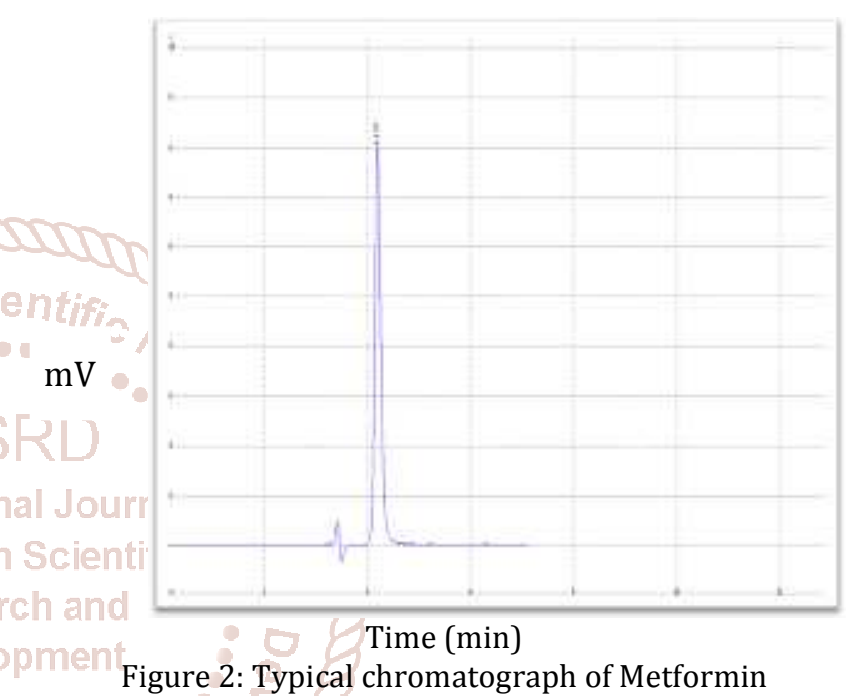

Hydrochloride

Validation of the RP-HPLC method

Validation of the optimized method was performed according to the ICH Q2 (R) guidelines.

\section{Linearity}

For the determination of linearity, appropriate aliquots were pipetted out from $1000 \mu \mathrm{g} / \mathrm{ml}$ (working stock solution). 0.1 $0.5 \mathrm{ml}$ was pipetted out in to a series of $10 \mathrm{ml}$ volumetric flasks and volume was made up with the solvent to obtain concentration ranging from $10-50 \mu \mathrm{g} / \mathrm{ml}$ of metformin. Each solution was injected in triplicate. Calibration curves were plotted with observed peak areas against concentration followed by the determination of regression equations and calculation of the correlation coefficients. The calibration curves for metformin was shown in figure 2 and their corresponding linearity parameters given in table 2 .

\section{Accuracy}

To ensure the reliability and accuracy of the method recovery studies were carried out by standard addition method. A known quantity of pure drug was added to preanalysed sample and contents were reanalysed by the proposed method and the percent recovery was reported. The results were given in table 4 .

\section{Precision}

The repeatability of the method was verified by calculating the $\%$ RSD of three replicate injections of $100 \%$ 
concentration $(30 \mu \mathrm{g} / \mathrm{ml}$ of Metformin) on the same day and for intraday precision \% RSD was calculated from repeated studies. The results were given in table 5 .

\section{Limit of Detection (LOD) and Limit of Quantitation (LOQ)}

The LOD and LOQ were calculated from the slope(s) of the calibration plot and the standard deviation (SD) of the peak areas using the formulae LOD $=4.2 \mathrm{~s} / \mathrm{s}$ and LOQ $=9.8 \mathrm{~s} / \mathrm{s}$.

\section{Robustness}

Robustness of the method was verified by altering the chromatographic conditions like mobile phase composition, flow rate, detection wave length, etc. and the \% RSD should be reported. Small changes in the operational conditions were allowed and the extent to which the method was robust was determined. A deviation of $\pm 2 \mathrm{~nm}$ in the detection wave length and $\pm 0.1 \mathrm{ml} / \mathrm{min}$ in the flow rate, were tried individually. Solutions of $100 \%$ test concentration with the specified changes in the operational conditions were injected to the instrument in triplicate. \% RSD was reported in the table 6 .

\section{Assay of marketed formulation}

20 tablets of teneligliptin were weighed and crushed into fine powder. The average weight of the tablet was calculated and the amount equivalent to $10 \mathrm{mg}$ of pure teneligliptin was dissolved in $10 \mathrm{ml}$ of solvent. From this stock solution 30 ppm dilution was prepared and injected. The $\%$ purity was calculated by comparing the result with result obtained from $30 \mathrm{ppm}$ standard drug and are reported in table 7.

\section{System suitability}

System suitability parameters can be defined as tests to ensure that the method can generate results of acceptable accuracy and precision. System suitability was carried out with three injections of solution of $30 \mu \mathrm{l} / \mathrm{ml}$ of Metformin in to the chromatographic system. Number of theoretical plates (N) obtained and calculated tailing factor (T) was reported in table 8 .

\section{Results and Discussion} Linearity:

Analytical method linearity is defined as the ability of the method to obtain test results that are directly proportional to the analyte concentration, within a specific range. The mean peak area obtained from the HPLC was plotted against corresponding concentrations to obtain the calibration graph. The results of linearity study (Figure 1) gave linear relationship over the concentration range of $10-50 \mu \mathrm{g} / \mathrm{ml}$ for metformin. From the regression analysis, a linear equation was obtained: $\mathrm{y}=31271 \mathrm{x}+49523$, and the goodness-of-fit $\left(\mathrm{r}^{2}\right)$ was found to be 0.9986 , indicating a linear relationship between the concentration of analyte and area under the peak.

Table 2: Summary of results of Linearity

\begin{tabular}{|c|c|}
\hline Conc. $(\mu \mathrm{g} / \mathrm{ml})$ & Peak Area \\
\hline 10 & 362718 \\
\hline 20 & 692265 \\
\hline 30 & 956735 \\
\hline 40 & 1308262 \\
\hline 50 & 1618262 \\
\hline
\end{tabular}

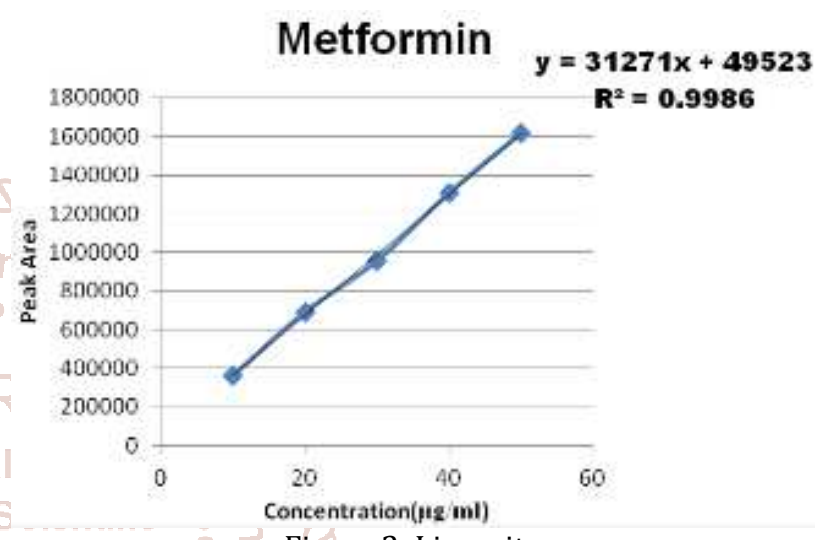

Figure 2: Linearity
Accuracy

The accuracy of an analytical procedure expresses the closeness of results obtained by that method to the true value. The results of accuracy testing showed that the method is accurate within the acceptable limits. The RSD is calculated for the metformin and all the results are within limits. Acceptable accuracy was within the range and not more than $2.0 \%$ RSD, as demonstrated in Table -3 .

\begin{tabular}{|c|c|c|c|c|c|c|}
\hline & & & \multicolumn{2}{|c|}{ Standard Deviation } & Accuracy & Precision \\
\hline Sr. no. & Conc. $(\mu \mathrm{g} / \mathrm{ml})$ & Area & Mean & SD & \%SD & \%RSD \\
\hline & 10 & 363165 & & & & \\
\hline 1 & 10 & 362718 & 363846.3333 & 1583.073698 & 0.435094 & 0.435094036 \\
\hline & 10 & 365656 & & & & \\
\hline 2 & 30 & 954648 & & & & \\
\hline & 30 & 956735 & 956247.3333 & 1419.769113 & 0.148473 & 0.148473001 \\
\hline & 50 & 957359 & & & & \\
\hline 3 & 50 & 1621245 & & & & \\
\hline & 50 & 1618262 & 1617829.333 & 3650.690939 & 0.2256536 & 0.22565365 \\
\hline
\end{tabular}

Table 3: summary of Results of Accuracy

\begin{tabular}{|c|c|c|c|c|}
\hline Sr. NO. & $\%$ Composition & Area of Standard & Area of Sample & $\%$ Recovery \\
\hline 1 & $50 \%$ Recovery & 956735 & 962945 & 100.6490826 \\
\hline 2 & $100 \%$ Recovery & 1308262 & 1285161 & 98.2342222 \\
\hline 3 & $150 \%$ Recovery & 1618262 & 1635968 & 101.0941368 \\
\hline
\end{tabular}

Table 4: \% recovery 


\section{Precision}

Precision of an analytical method is defined as "the closeness of agreement between a series of measurements obtained from multiple sampling of the same homogeneous sample under the prescribed conditions," and it is normally expressed as the relative standard deviation The repeatability, intra-day and inter-day precision results are shown in the table 5 . The RSD were calculated for all the results are within limits. Precision was not more than $2.0 \%$ RSD, as demonstrated in Table 5 .

\begin{tabular}{|c|c|c|c|c|c|c|c|c|}
\hline & Interday & Day 1 & & & Day 2 & & Mean & \%RSD \\
\hline Injection & 1 & 2 & 3 & 1 & 2 & 3 & & \\
\hline area & 956735 & 963535 & 956973 & 955612 & 958412 & 956332 & 956332 & $0.30 \%$ \\
\hline & Intraday & Morning & & & Evening & & & $\%$ RSD \\
\hline Injection & 1 & 2 & 3 & 1 & 2 & 3 & & \\
\hline area & 956898 & 962415 & 958615 & 957651 & 956526 & 954516 & 957770.2 & $0.28 \%$ \\
\hline
\end{tabular}

\section{LOD and LOQ}

Table-5: summary of Precision

The LOD and LOQ were calculated by the equations LOD $=\frac{3.3 \times a t d . D e v i a t i o n}{\text { slope }}$ and LOQ $=\frac{10 \times a t d . D e r i a t i o n}{\text { slope }}$ where, std. Deviation taken from accuracy and slope is from linearity. Based on these equations, the calculated LOD and LOQ values for metformin were 0.1502 and $0.4553 \mu \mathrm{g} / \mathrm{ml}$, respectively.

\section{Robustness}

Robustness of the method reflects the reliability of an analysis with respect to deliberate variations in the method parameters. Here, the flow rate and wavelength were slightly changed to lower and higher sides of the actual values to find if the change in the peak area and retention time were within limits. The results obtained with changes in the parameters on a $30 \mu \mathrm{g} / \mathrm{mL}$ solution are as shown in Table No. 6.

\begin{tabular}{|c|c|c|c|c|c|c|c|c|}
\hline Sr.no. & Parameter & Condition & Peak Area & & $\begin{array}{c}\text { Statistical } \\
\text { Analysis }\end{array}$ & \begin{tabular}{|c|c}
$\begin{array}{c}\text { Retention } \\
\text { Time }\end{array}$ \\
\end{tabular} & & $\begin{array}{c}\text { Statistical } \\
\text { Analysis }\end{array}$ \\
\hline \multirow{7}{*}{1} & \multirow{7}{*}{ Flow rate } & \multirow{3}{*}{0.9} & 973735 & \multirow{2}{*}{$\begin{array}{c}\text { Mean }= \\
965818.333\end{array}$} & \multirow{2}{*}{$\begin{array}{c}\text { Mean }= \\
961906.889\end{array}$} & 4.296 & \multirow{3}{*}{$\begin{array}{c}\text { mean= } \\
4.29266667\end{array}$} & \multirow{3}{*}{$\begin{array}{c}\text { mean }= \\
4.22377778\end{array}$} \\
\hline & & & 966735 & & & 4.296 & & \\
\hline & & & 956985 & & \multirow{5}{*}{$\begin{array}{c}\mathrm{SD}= \\
4671.00377 \\
\% \mathrm{RSD}= \\
0.48559833\end{array}$} & 4.286 & & \\
\hline & & 1 & 80 & 956735 & & 3 & 4.203 & $S D=$ \\
\hline & & \multirow{3}{*}{1.1} & 964921 & \multirow{3}{*}{$\begin{array}{c}\text { Mean }= \\
963167.333\end{array}$} & & 4.162 & \multirow{3}{*}{$\begin{array}{c}\text { mean }= \\
4.17566667\end{array}$} & 0.06120488 \\
\hline & & & 971366 & & & 4.186 & & $\% \mathrm{RSD}=$ \\
\hline & & & 953215 & & & 4.179 & & 1.44905534 \\
\hline \multirow{7}{*}{2} & \multirow{7}{*}{ Wavelength } & \multirow{3}{*}{236} & 950121 & \multirow{3}{*}{$\begin{array}{l}\text { Mean }= \\
950218\end{array}$} & \multirow{4}{*}{$\begin{array}{c}\text { mean }= \\
952424.333\end{array}$} & 4.213 & \multirow{3}{*}{$\begin{array}{c}\text { mean }= \\
4.20933333\end{array}$} & \multirow{4}{*}{$\begin{array}{c}\text { mean= } \\
4.206\end{array}$} \\
\hline & & & 951264 & & & 4.209 & & \\
\hline & & & 949269 & & & 4.206 & & \\
\hline & & 238 & & & & & 4.203 & \\
\hline & & \multirow{3}{*}{240} & 948963 & mean $=$ & \multirow{3}{*}{$\begin{array}{c}3733.49519 \\
\% R S D= \\
0.39199914\end{array}$} & 4.206 & \multirow{3}{*}{$\begin{array}{c}\text { mean }= \\
4.20566667\end{array}$} & \multirow{3}{*}{$\begin{array}{c}0.0031798 \\
\% \mathrm{RSD}= \\
0.07560146\end{array}$} \\
\hline & & & 949632 & 950320 & & 4.203 & & \\
\hline & & & 952365 & & & 4.208 & & \\
\hline
\end{tabular}

Table 6: robustness

\section{Assay of marketed formulation}

The \% purity obtained from the formulation was given in table 7. And it was found that the Assay results of Metformin are within the limits.

\begin{tabular}{|c|c|c|c|c|}
\hline Sr. NO. & $\%$ Composition & Area of Standard & Area of Sample & $\%$ Assay \\
\hline 1 & \% Assay & 956735 & 945995 & 98.8774 \\
\hline
\end{tabular}

Table 7: Assay of tables of Metformin Hydrochloride

\section{System Suitability Parameters:}

System suitability was carried out by injecting six replicate injections of $100 \%$ test concentration, number of theoretical plates, HETP and resolution were satisfactory. The chromatograms confirm the presence of Metformin hydrochloride at 4.2 min without any interference.

\begin{tabular}{|c|c|c|}
\hline Parameter & Observed Value & limits \\
\hline No. of Theoretical Plates & 5630 & $>2000$ \\
\hline Tailing Factor & 1.2 & $<1.5$ \\
\hline Regression equation & $\mathrm{y}=31271 \mathrm{x}+49523$ & \\
\hline Correlation coefficient $\left(\mathrm{R}^{2}\right)$ & 0.9986 & $\sim 1$ \\
\hline
\end{tabular}

Table 8: System suitability parameter 


\section{CONCLUSION:}

The proposed method was found to be simple, precise, accurate, rapid and specific for determination of metformin hydrochloride from pure and its dosage forms. The mobile phase is simple to prepare and economical. The sample recoveries in the formulation were in good agreement with their respective label claims and they suggested noninterference of formulation excipients in the estimation. Hence, this method can be easily and conveniently adopted for routine analysis of Metformin hydrochloride in pure form and its dosage form.

\section{ACKNOWLEDGEMENT}

Author gratefully acknowledges Mr. Rohan Pawar, the Director, the RAP Analytical Research and Training Center for their kind help and providing all necessary facilities and also for providing the guidance to the mark.

\section{REFERNCES}

[1] Langtry HD, Benfield P. Zolpidem: a review

[2] Maruthur NM, Tseng E, Hutfless S, Wilson LM, SuarezCuervo C, Berger Z, Chu Y, Iyoha E, Segal JB, Bolen S (June 2016). "Diabetes Medications as Monotherapy or Metformin-Based Combination Therapy for Type 2 Diabetes: A Systematic Review and Metaanalysis". Annals of Internal Medicine. 164 (11): 74051.

[3] Dunn CJ, Peters DH (May 1995). "Metformin. A review of its pharmacological properties and Therapeutic Use in non-insulin-dependent diabetes mellitus". Drugs. 49 (5): 721-49.

[4] Hundal RS, Inzucchi SE (2003). "Metformin: new understandings, new uses". Drugs. 63 (18): 1879-94.

[5] "Type 2 diabetes and metformin. First choice for monotherapy: weak evidence of efficacy but wellknown and acceptable adverse effects". Prescrire International. 23 (154): 269-72. November 2014

[6] Deya S, Patrob SS, Babu NS, Murthy PN, Panda SK. Development and validation of a stability-indicating RP-HPLC method for estimation of atazanavir sulfate in bulk. JPA. 2011; 201; 12

[7] Li M, Hou XF, Zhang J, Wang SC, Fu Q, et al. Applications of HPLC/MS in the analysis of traditional Chinese medicines (Review). JPA. 2011; 1(2): 81-91

[8] Khuda F, Iqbal Z, Shah Y, Ahmmad L, Nasir F, et al. Method development and validation for simultaneous determination of lumefantrine and its major metabolite, desbutyl lumefantrine in human plasma using RP-HPLC/UV detection. Journal of Chromatography B. 2014; 944: 114122.

[9] Nouruddin W, Gamala M, Abdelkawy A. Simultaneous determination of hyoscine N-butyl bromide and paracetamol in their binary mixture by RP-HPLC method. The Arabian Journal of Chemistry. 2013 